$$
\begin{gathered}
\text { AL.2.2004-273 } \\
\text { C.2 }
\end{gathered}
$$

\title{
FORAGE GROWTH AND NUTRIENT CYCLE OF ASPEN FOREST COMMUNITIES IN ALBERTA'S LOWER FOOTHILLS SUBREGION
}
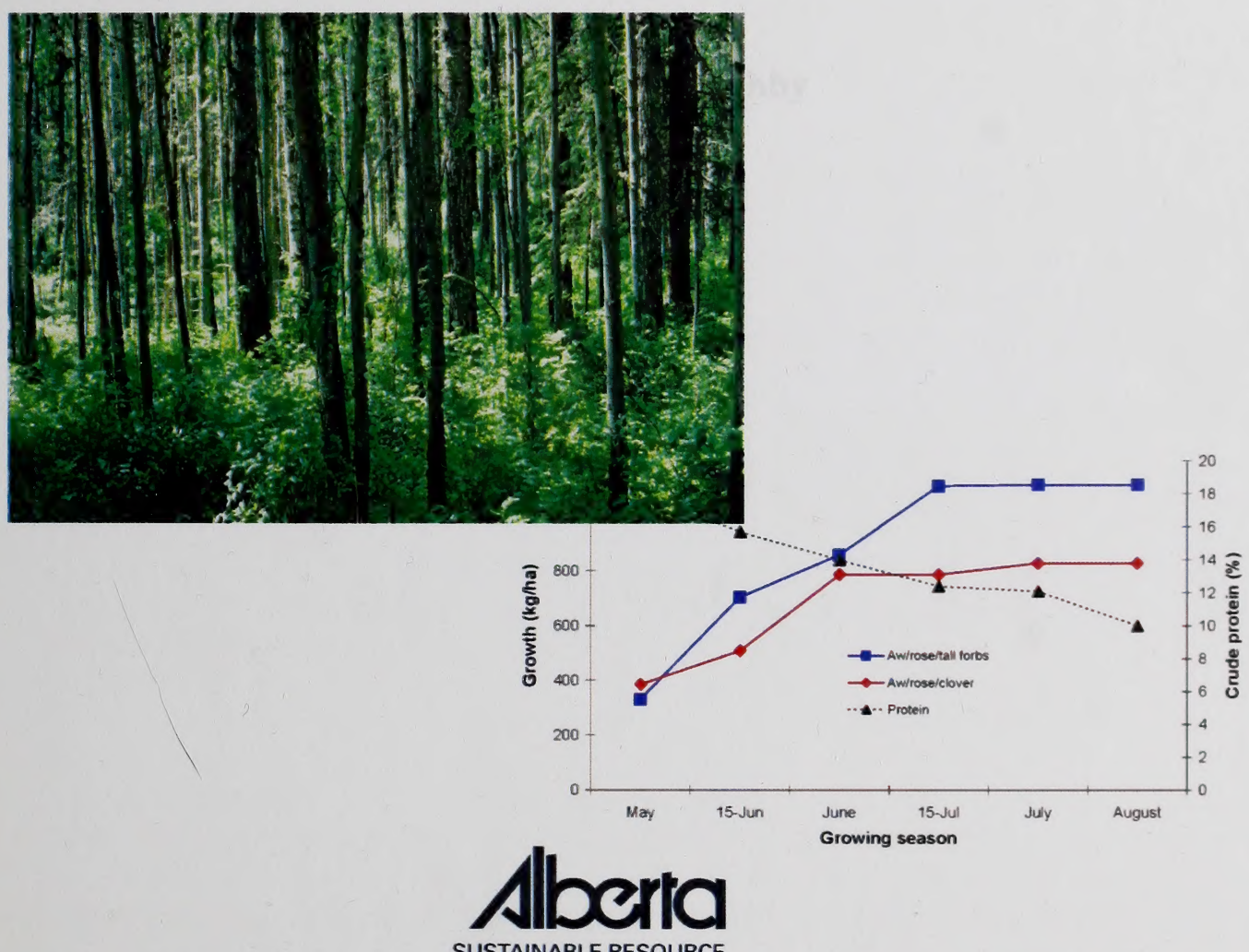

SUSTAINABLE RESOURCE DEVELOPMENT

Public Lands $\&$ Forests 



\title{
FORAGE GROWTH AND NUTRIENT CYCLE OF ASPEN FOREST COMMUNITIES IN ALBERTA'S LOWER FOOTHILLS SUBREGION
}

\author{
Prepared by \\ Michael G. Willoughby \\ and \\ Cam T.P. Lane
}




\section{Pub No. T/064}

ISBN No. 0075-3630-0 Printed edition

ISBN No. 0075-3631-9 On-line edition

For copies of this report contact:

\section{Michael Willoughby}

(780) 422-4598

E-mail: mike.willoughby@gov.ab.ca 
Digitized by the Internet Archive in 2016 


\section{Table of Contents}

Introduction

Site description

Methods

Results $\quad 4$

Forage growth 4

$\begin{array}{lc}\text { Defoliation and yield } & 6\end{array}$

$\begin{array}{lr}\text { Forage quality } & 8\end{array}$

Discussion $\quad 9$

$\begin{array}{ll}\text { Forage growth } & 9\end{array}$

Defoliation and yield 9

$\begin{array}{lr}\text { Forage quality } & 10\end{array}$

$\begin{array}{ll}\text { Literature cited } & 10\end{array}$

\section{List of Figures}

Figure 1. Total monthy forage growth and crude protein over two years for the Rose/Tall forb and Rose/Clover types

4

Figure 2. Total production for Treatment 1 (T1) and Treatment 6 (T6) at the end of August $(1998,1999)$ with the same plots reclipped in May $(1999,2000)$ for the Rose/Tall forb site.

7

\section{List of Tables}

Table 1. Clip treatments for 1998 and 1999 at the Aspen/Rose/Clover and Aspen/Rose/Tall forb dominated sites.

Table 2. Mean Monthly Temperature $\left({ }^{\circ} \mathrm{C}\right)$ and Monthly Precipitation (mm) in 1998 and 1999.

Table 3. Average production $(\mathrm{kg} / \mathrm{ha})$ in the various treatments for grass, forbs, shrubs and total at 
Table 4. Crude protein (\%CP) and total digestible nutrients (\%TDN) for grass, forbs and shrubs for both sites combined during 1998 and 1999.

8

\section{List of Photos}

Photo 1. Aspen/Rose/Clover dominated community type.

Photo 2. Aspen/Rose/Tall forb dominated community type. 


\begin{abstract}
Aspen forest communities are the principal foraging areas for domestic livestock in the undisturbed boreal forest. Little is known about the forage growth cycle and the effects of grazing on these northern communities. The seasonal forage production cycle and effect of six clipping frequencies were studied in two aspen community types. One site represented a Healthy with problems (Adams et al. 2003) aspen stand and was dominated by prickly rose (Rosa acicularis) and clover (Trifolium spp.). The other site represented a Healthy aspen stand and was dominated by prickly rose (Rosa acicularis), marsh reedgrass (Calamagrostis canadensis) and yellow peavine (Lathyrus ochroleucus). Plots were clipped biweekly from June 1 to September 1. Increased frequency of clipping had little effect on forage production. Treatments clipped in June and early July tended to have the highest production compared to plots clipped in late July and August. The majority of the forage in these stands is forbs, which tended to grow earlier in the season and then ceased growth. Nutrient analysis indicated that shrubs and forbs were of high quality in June and early July averaging $15-16 \%$ crude protein, declining to 12 and $11 \%$ in late August. In contrast the crude protein content of grass was only $13 \%$ in June and declined to $10 \%$ in late August. In order to maximize production and forage quality of these boreal forest communities grazing should occur in July.
\end{abstract}





\section{Introduction}

Sustainable Resource Development has a mandate to ensure the benefits Albertans receive from Alberta's public land and natural resources (forests, rangelands, fish and wildlife) are achieved in a manner that is sustainable, equitable, responsible and in the public interest. As the need to intensify management increases, more detailed information and an improved understanding of the range and other resources are essential.

The deciduous forest communities of Alberta cover over 6.8 million ha and are a classic example of multiple use forest land. These communities are important for forestry, recreation and wildlife use. They are also the principal foraging areas for domestic livestock. Despite their importance, little is known about the forage growth and nutrient cycle and the effects of grazing on these communities. This makes it difficult to determine proper turnout dates, length of the grazing season, stocking rates and carrying capacity.

To enhance our knowledge about the effects of continuous and rotational grazing on forage productivity in deciduous communities, a clipping trial was established at two sites near Edson. The specific objectives included: 1. To determine the forage growth and nutrient cycle of grasses, forbs and shrubs in a Aspen/Rose/Tall forb and an Aspen/Rose/Clover community type (Lane et al. 2000) 2. Correlate growth with precipitation and air temperature and 3. To determine the effect of continuous versus rotational grazing on the forage and nutrient productivity of grasses, forbs and shrubs in the two community types.

\section{Site description}

The clipping trial was located on a grazing disposition located approximately $20 \mathrm{~km}$ northeast of Edson. The sites were within the Lower Foothills subregion (Environmental Protection 1994). The average summer precipitation for this region ranges from $230 \mathrm{~mm}$ to $450 \mathrm{~mm}$, with the majority of the subregion receiving between 300 and $400 \mathrm{~mm}$ of precipitation. The average summer temperature ranges between 10.0 to $12.5^{\circ} \mathrm{C}$.

The two sites represented a low-bush cranberry ecological site, which is regarded as the reference site for the Lower Foothills subregion because of the medium nutrient regime and the mesic moisture regime (Beckingham et al. 1992). Both sites had slightly different levels of grazing disturbance. The first site was represented by the moderately to heavily grazed Aspen/Rose/Clover community (Lane et al. 2000) (Photo 1). The second site had no history of grazing pressure and was representative of the Aspen/Rose/Tall forb community type (Lane et al. 2000)(Photo 2). 



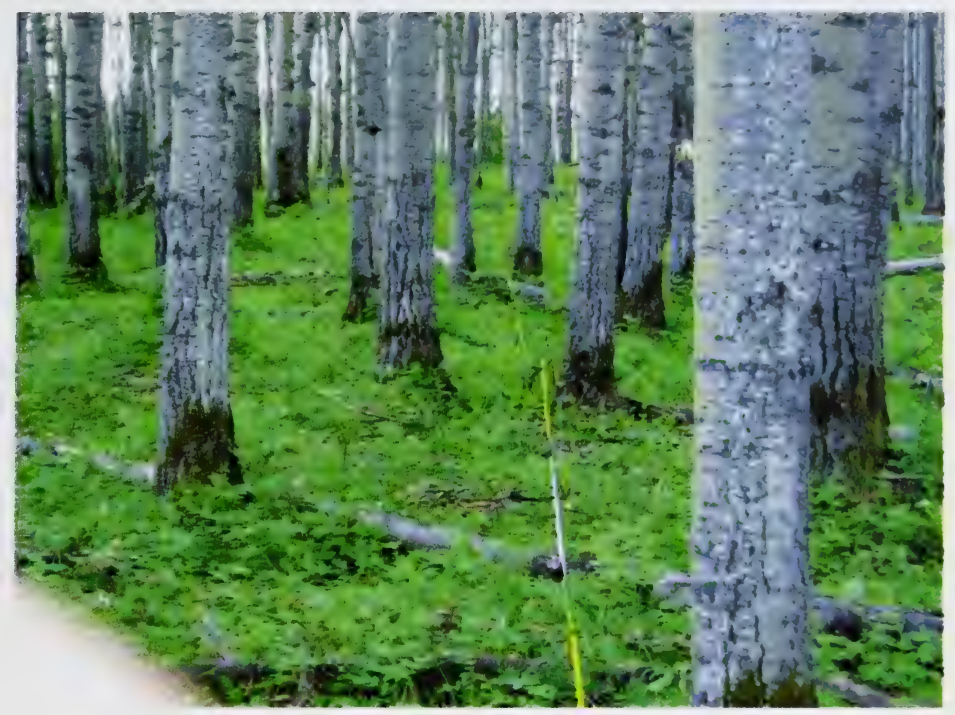

Photo 1. Aspen/Rose/Clover dominated community type.

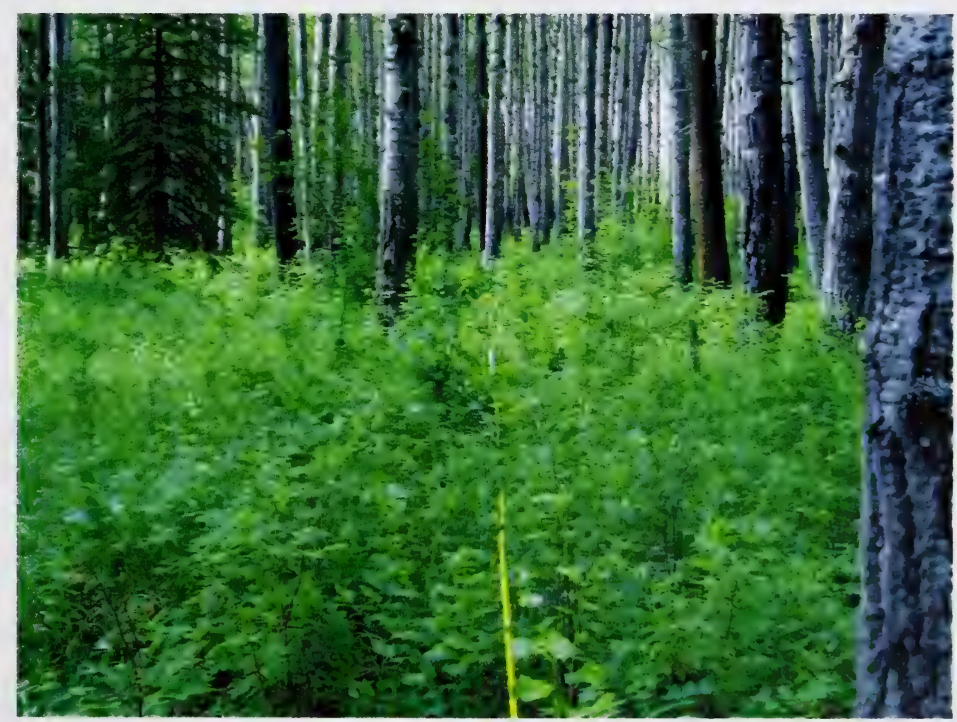

Photo 2. Aspen/Rose/Tall forb dominated community type. 



\section{Methods}

Beginning in 1998, six treatments were clipped for two consecutive years. The clipping treatments are outlined in Table 1 and were applied to a site that had been moderately to heavily grazed (Aspen/Rose/Clover) and a ungrazed site (Aspen/Rose/Tall forb).

Table 1. Clip treatments for 1998 and 1999 in the Aspen/Rose/Clover and Aspen/Rose/Tall forb dominated sites.

\begin{tabular}{|l|c|c|c|c|c|c|}
\hline Treatments & May & Jun-15 & June & Jul-15 & July & August \\
\hline $\begin{array}{l}\text { T1- } \\
\text { Continuous }\end{array}$ & Clip & & Reclip & & Reclip & Reclip \\
\hline $\begin{array}{l}\text { T2-15 day } \\
\text { deferral }\end{array}$ & & Clip & & & & Reclip \\
\hline $\begin{array}{l}\text { T3-30 day } \\
\text { deferral }\end{array}$ & & & Clip & & & Reclip \\
\hline $\begin{array}{l}\text { T4-45 day } \\
\text { deferral }\end{array}$ & & & Clip & & Reclip \\
\hline $\begin{array}{l}\text { T5-60 day } \\
\text { deferral }\end{array}$ & & & & & Clip & Reclip \\
\hline $\begin{array}{l}\text { T6 } \\
\text { (Control) }\end{array}$ & & & & & & Clip \\
\hline
\end{tabular}

The clipping treatments represent a greater deferral of grazing and include T1 continuous (Clipped every month starting in May), T2- 15-June deferral (Clipped in the middle of June and reclipped at the end of August), T3- June deferral (Clipped at the end of June and reclipped at the end of August), T4- 15-July deferral (Clipped in the middle of July and reclipped at the end of August), T5- July deferral (Clipped at the end of July and reclipped at the end of August), T6- Control (Clipped at the end of August).

There were ten replicates for each treatment and these were randomized over each year at each site. The six levels of clipping treatment and year, were randomly assigned to 10 blocks within a $20 \times 40 \mathrm{~m}$ exclosure at each site. The treatments were analyzed as a split-plot in time. Each clip was from a $50 \times 100 \mathrm{~cm}$ quadrat and was sorted to grass, forbs, shrubs and trees, oven dried for 24 hours at $30^{\circ} \mathrm{C}$.

In 1999 and 2000, treatments T1 and T6, from 1998 and 1999 were reclipped at the end of May and tested to see if the previous years clipping treatment had significantly affected forage production at both sites. 

Samples of grass, forb and shrub were also analyzed for percentage crude protein, total digestible nutrients (TDN), digestible energy (DE), percent phosphorus and calcium for each month from combined samples at each site.

\section{Results}

\section{Forage growth}

There was significantly higher production and growth rates on the Aw/Rose/Tall forb community compared to the Aw/Rose/Clover dominated community (Figure 1). Total forage growth of grass, forbs and shrubs in grazed and ungrazed deciduous communities started in May and generally peaked by the middle of July for both years (Figure 1). By the end of July grass, forb and shrub growth had ceased at both sites (Figure 1).

\section{Figure 1. Total monthly forage growth and crude protein over two years for the Rose/Tall forb and Rose/Clover comm unities}

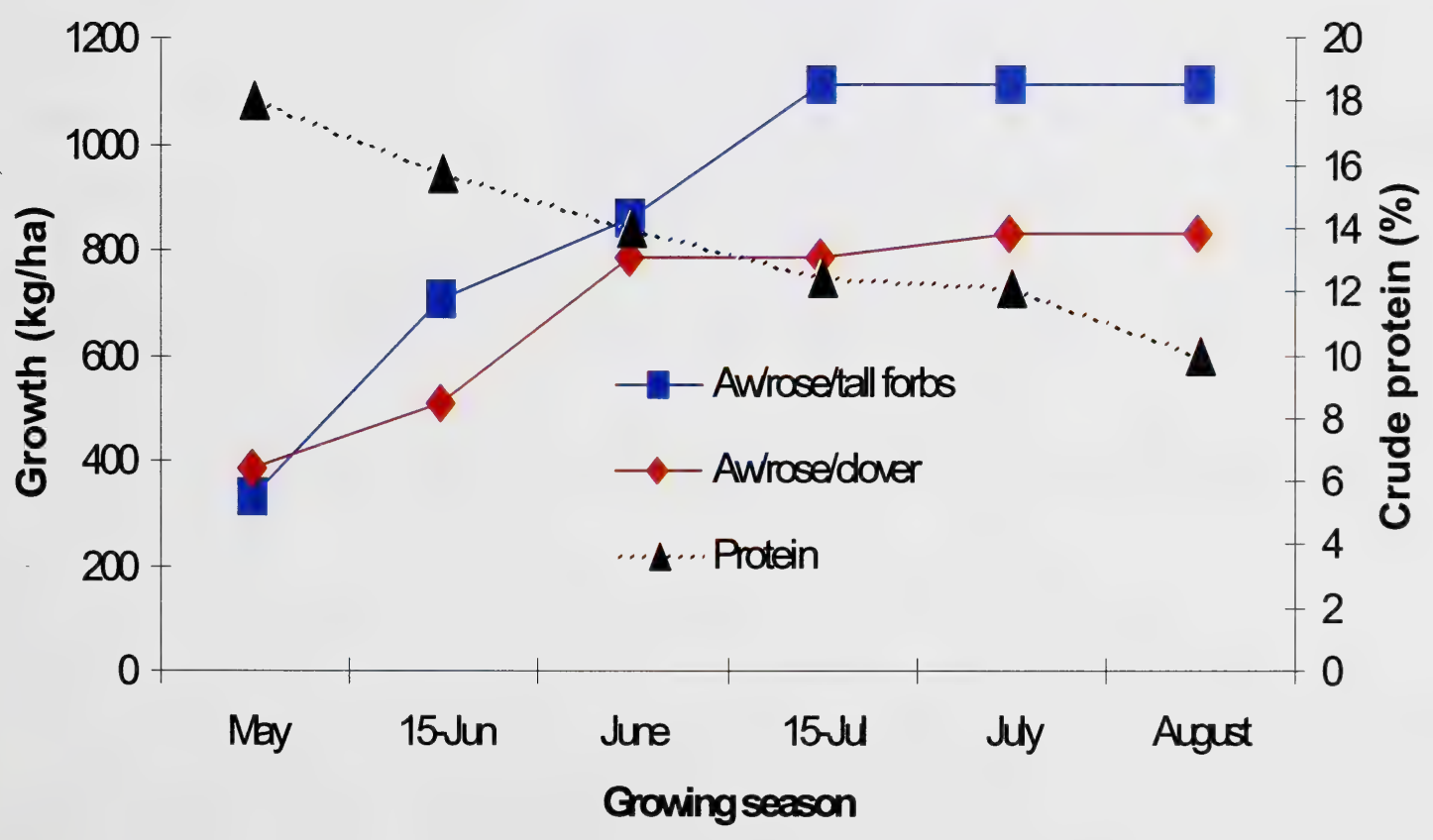



Warmer 1998 spring temperatures increased the rate of forage growth in May compared to May 1999 growth rates because of cooler spring temperatures (Table 2).

Table 2: Mean Monthly Temperature $\left({ }^{\circ} \mathrm{C}\right)$ and Monthly Precipitation (mm) in 1998 and 1999.

\begin{tabular}{lcccc} 
& 1998 & 1998 & 1999 & 1999 \\
\cline { 2 - 5 } Month & Temp. & Ppt. & Temp. & Ppt. \\
\hline April & 5 & 0 & 4 & 28 \\
May & 12 & 65 & 8 & 78 \\
June 15 & 11 & 34 & 11 & 4 \\
June & 14 & 55 & 13 & 38 \\
July 15 & 16 & 18 & 13 & 87 \\
July & 17 & $T$ & 14 & 7 \\
August & 16 & 72 & 15 & 47 \\
\hline Avg./Total & 15 & 244 & 13 & 289
\end{tabular}

Note: Average precipitation for April-August is $324 \mathrm{~mm}$ from Shining Bank weather station. 



\section{Defoliation and yield}

Increased frequency of clipping had little effect on forage production. Treatments clipped in June and July (T1-T5) had significantly higher production for grass, forbs and total than the control treatment clipped at the end of August (T6) for both sites (Table 3). However when the 1998 control treatment (T6) and the continuous treatment (T1) were reclipped in May 1999 and the 1999 treatments were reclipped again in May 2000 the control treatment had significantly higher production at both sites (Figure 2).

Table 3. Average production $(\mathrm{kg} / \mathrm{ha})$ in the various treatments for grass, forbs, shrubs and total at the Aspen/Rose/Clover and Aspen/Rose/Tall forb sites for 1998 and 1999.

\begin{tabular}{lcccc} 
Treatment & Grass & Forbs & Shrub & Total \\
\hline Rose/Clover & & & & \\
T1 (continuous) & $119 \mathrm{a}$ & $585 \mathrm{a}$ & $264 \mathrm{ab}$ & $972 \mathrm{a}$ \\
T2-15 day & $67 \mathrm{ab}$ & $422 \mathrm{bc}$ & $230 \mathrm{~b}$ & $722 \mathrm{bc}$ \\
T3-30 day & $67 \mathrm{ab}$ & $542 \mathrm{ab}$ & $369 \mathrm{a}$ & $978 \mathrm{a}$ \\
T4-45 day & $40 \mathrm{~b}$ & $457 \mathrm{ab}$ & $283 \mathrm{ab}$ & $780 \mathrm{ab}$ \\
T5-60 day & $68 \mathrm{ab}$ & $424 \mathrm{bc}$ & $284 \mathrm{ab}$ & $778 \mathrm{ab}$ \\
T6 (control) & $69 \mathrm{ab}$ & $295 \mathrm{c}$ & $206 \mathrm{~b}$ & $570 \mathrm{c}$ \\
Rose/Tall forb & & & & \\
T1 (continuous) & $374 \mathrm{~b}$ & $391 \mathrm{a}$ & $261 \mathrm{a}$ & $1025 \mathrm{ab}$ \\
T2-15 day & $409 \mathrm{ab}$ & $316 \mathrm{a}$ & $240 \mathrm{a}$ & $969 \mathrm{~b}$ \\
T3-30 day & $370 \mathrm{~b}$ & $336 \mathrm{a}$ & $301 \mathrm{a}$ & $1034 \mathrm{ab}$ \\
T4-45 day & $409 \mathrm{ab}$ & $390 \mathrm{a}$ & $258 \mathrm{a}$ & $1219 \mathrm{a}$ \\
T5-60 day & $441 \mathrm{ab}$ & $334 \mathrm{a}$ & $271 \mathrm{a}$ & $1046 \mathrm{ab}$ \\
T6 (control) & $345 \mathrm{~b}$ & $198 \mathrm{~b}$ & $178 \mathrm{a}$ & $721 \mathrm{c}$ \\
\hline
\end{tabular}

Note: Means with the same letter within a column and within a site are not significantly different according to an SNK test at the $\mathrm{P}<0.05$ level. 

Figure 2 Total production for treatment (T1) and treatment (T6) at the end of August $(1998,1999)$ with the same plots reclipped in $\operatorname{May}(1999,2000)$ for the Rose/Tall forb site

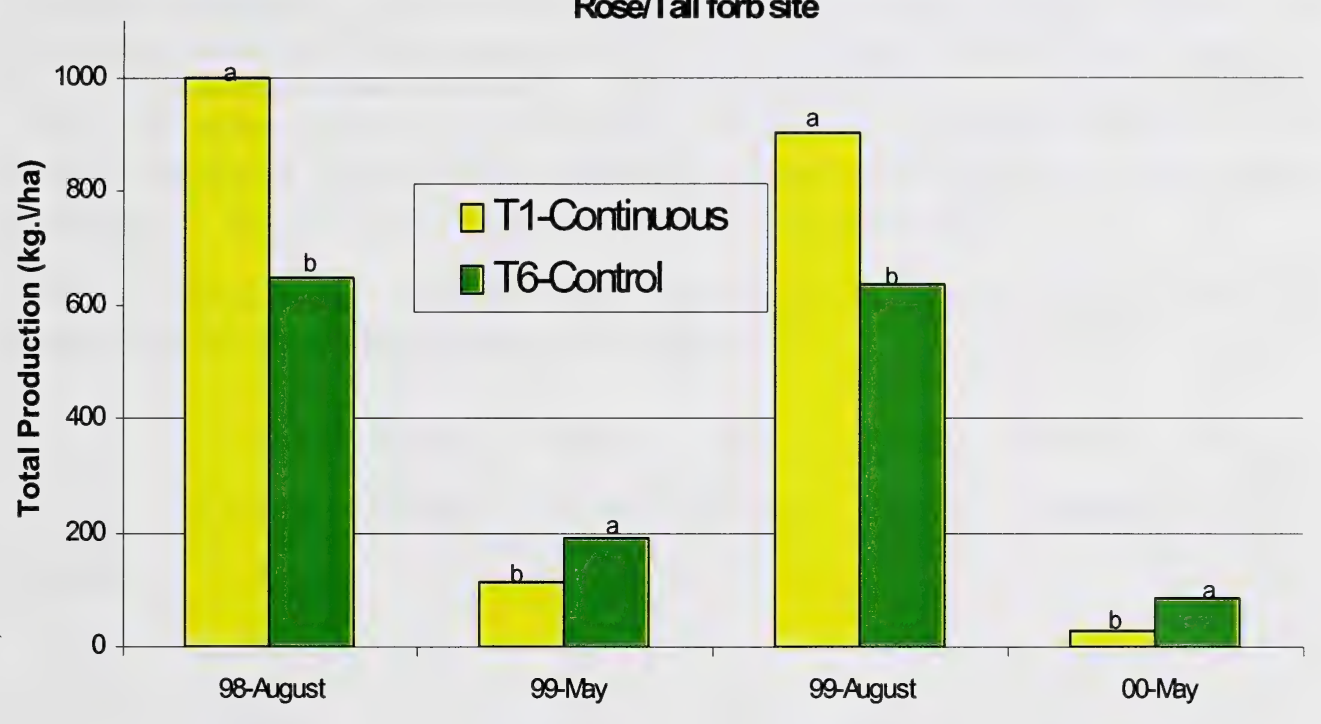

Note: Yearly means with the same letter are not significantly different according to an SNK test at $\mathrm{p}<0.05$ level. 



\section{Forage quality}

Total combined crude protein for grass, forbs and shrubs averaged over $18 \%$ in May and declined to $10 \%$ by the end of August for both years combined (Figure 1). Grasses had the lowest crude protein values averaging over the two years from a high of $15 \%$ in May to less than $9 \%$ at the end of August. In contrast shrubs had the highest protein content averaging over $20 \%$ in May and declining to $11 \%$ at the end of August (Table 4). Total Digestible Nutrients (TDN) averaged over $60 \%$ for grasses, forbs, and shrubs for every month combined over the two years. Grasses had the lowest TDN averaging over $50 \%$ in both years, whereas shrubs averaged over $70 \%$ TDN in 1998 and over $80 \%$ in 1999 (Table 4). Grasses had the lowest percentage of calcium and phosphorus averaging 0.39 and 0.32 in early June and 0.55 and 0.23 at the end of August, respectively. In contrast forbs had the highest percentage of calcium and phosphorus averaging 0.99 and 0.41 in early June and 1.93 and 0.4 in late August.

Table 4. Crude protein $(\% \mathrm{CP})$ and total digestible nutrients $(\% \mathrm{TDN})$ for grass, forbs and shrubs for both sites combined during 1998 and 1999.

\begin{tabular}{lcccccccc} 
& $\begin{array}{ccccc}\text { Grass } \\
\text { \%CP }\end{array}$ & $\begin{array}{c}\text { Grass } \\
\text { \%TDN }\end{array}$ & $\begin{array}{c}\text { Forb } \\
\text { \% CP }\end{array}$ & $\begin{array}{c}\text { Forb } \\
\text { \%TDN }\end{array}$ & $\begin{array}{c}\text { Shrub } \\
\text { \%CP }\end{array}$ & $\begin{array}{c}\text { Shrub } \\
\text { \%TDN }\end{array}$ & $\begin{array}{c}\text { Avg. } \\
\text { \%CP }\end{array}$ & $\begin{array}{c}\text { Avg. } \\
\text { \%TDN }\end{array}$ \\
\hline $\mathbf{1 9 9 8}$ & & & & & & & & \\
May & 13.4 & 53 & 18.1 & 70 & 16.9 & 83 & 16.1 & 69 \\
June & 12.1 & 51 & 14.9 & 69 & 14.2 & 74 & 13.7 & 65 \\
July & 12 & 54 & 11.6 & 64 & 12 & 73 & 11.9 & 64 \\
August & 9.7 & 41 & 10.8 & 60 & 11.5 & 71 & 10.7 & 57 \\
1999 & & & & & & & & \\
May & 15.8 & 64 & 20 & 74 & 23.5 & 84 & 19.8 & 74 \\
June & 12.4 & 57 & 18.4 & 67 & 15.3 & 83 & 15.4 & 69 \\
July & 10.2 & 54 & 12.8 & 66 & 14.5 & 82 & 12.5 & 67 \\
August & 7.4 & 59 & 10.8 & 72 & 9.9 & 83 & 9.4 & 71 \\
\hline
\end{tabular}





\section{Discussion}

\section{Forage growth}

Most grass, forb and shrub growth occurred in June and July at both the Rose/Clover and Rose/Tall forb dominated sites. Cool spring temperatures tended to delay growth extending forage growth until the end of July, but by the end of August total forage production stopped at both sites because of the rapid senescence of forbs and shrubs. This growth pattern is very different from tame pastures. Smith et al. (1995), found that grass growth of non-native agronomic species in the same area continued growing until the end of September and forbs continued to grow until the end of August. Despite the short growing season in aspen dominated communities compared to tame forages the aspen understory is extremely important especially during years of drought. Willoughby (2004) found during the drought years of 2001 and 2002 in North central Alberta forage continued to grow in the aspen understory, but had ceased to grow in the tame pasture community types. Forage growth in the aspen dominated communities was not significantly lower until 2003 a year after the drought (Willoughby 2004).

\section{Defoliation and yield}

Increased defoliation had little affect on forage production within the current growing season. Treatments that were clipped in June or July tended to have higher production than the control treatment clipped once at the end of August. Forage production actually declined over $500 \mathrm{~kg} / \mathrm{ha}$ from plots clipped at the end of July to plots clipped at the end of August because of the rapid senescence of forbs in the ungrazed Aspen/Rose/Tall forb community in both years.

Forage production on the continuously clipped treatment was 40-65\% lower compared to the control when the same plots were clipped in May of the next growing season. Severe defoliation often affects the ability of plants to regrow by reducing carbohydrate reserves (Menke and Trilica 1981, Bahrani et al. 1983, Richards and Caldwell 1985). Severe defoliation coupled with winter respiration affected the ability of the plants to regrow the next growing season reducing total forage production. These defoliation effects are very different from tame pasture communities. Continuous defoliation over the growing season in tame pastures significantly reduced total forage production compared to a rotational grazing system (Smith et al. 1995).

Willoughby (1995) and Lane et al. (2000) found that prolonged moderate to heavy grazing pressure on deciduous communities in the Lower Foothills subregion caused the canopy cover of the shrub and forb layer to decline and there was an increase in low forbs, strawberry, bunchberry, wintergreen and clover species to form the Aw/Rose/Clover dominated community type. As grazing pressure became severe they found that the native plant species declined in cover and were often replaced by Kentucky bluegrass, dandelion and clover species. These species composition changes caused by increased grazing pressure severely affect the ability of the plant community to grow. Forage growth and production was $25-40 \%$ lower in the Aspen/Rose/ Clover dominated community than the ungrazed Aspen/Rose/Tall forb dominated community for both years of the study. 

Experience has shown that there is little regrowth of these community types after clipping or grazing. In order to sustain the production on these deciduous community types they are probably best suited to one rotation/year in the peak of the growing season.

\section{Forage quality}

Forage quality of these aspen dominated community types is extremely high. Nutrient analysis indicates that nutrient quality of shrubs and forbs exceeds the quality of fresh cut alfalfa in early June and by the end of August combined nutrients of grasses, forbs and shrubs exceeds the nutrient quality of timothy and bromegrass hay (Maynard et al. 1979). Willoughby (1995) has also found that carrying capacity calculations which allowed for $25 \%$ use of total forage production appears to be the level of utilization that can sustain an aspen community in good condition. These results suggest the best way to maximize nutrients and sustain long term productivity of these deciduous communities would be a one time grazing in July at $25 \%$ utilization of the total forage production.

\section{Literature cited}

Adams, B.W., G. Ehlert, C. Stone, D. Lawrence, M. Alexander, M. Willoughby, C. Hincz, D. Moisey, and A.Bogen. 2003. Rangeland Health Assessment for Grassland, Forest and Tame Pasture. Alberta Sustainable Resource Development. Public Lands Division. Edmonton. AB. Pub. No. T/044. 104pp.

Bahrani, J., E.R. Beaty, and K.H. Tan. 1983. Relationships between carbohydrate, nitrogen contents and regrowth of tall fescue tillers. J. Range. Manage. 36: 234-235.

Beckingham, J., I.G.W. Corns and J.H. Archibald. 1996. Field Guide to ecosites of WestCentral Alberta. Special report 9. Canadian Forest Service. Northwest Region. Northern Forestry Centre.

Department of Environmental Protection. 1994. Natural Regions of Alberta. Alberta Environmental Protection. Edmonton, Alta. Pub. no.: I/531. 18pp.

Lane, C.T., M.G. Willoughby and M.J. Alexander. 2000. Range plant communities and carrying capacity for the Lower Foothills subregion. $3^{\text {rd }}$ approximation. Alberta Environment. Land and Forest Service. Edmonton. AB. Pub. No. T/532. 232pp.

Maynard, L.A., J.K. Loosli, H.F. Huntz, and R.G. Warner. 1979. Animal Nutrition. McGraw Hill Book Company. New York. 602pp.

Menke, J.W. and M.J. Trilica. 1981. Carbohydrate reserve, phenology and growth cycle of nine Colorado range species. J. Range Manage. 34: 269-277. 
Richards, J.H. and M.M. Caldwell. 1985. Soluble carbohydrates, concurrent photosynthesis and efficiency in regrowth following defoliation: A field study with Agropyron species. J. of Appl. Ecol. 22:907-920.

Smith, D., M.G. Willoughby and J. Bauer. 1995. Forage growth and the effect of Continous versus Rotational grazing on forage production in the Dry Mixedwood subregion of Alberta. Environmental Protection. Rocky Mountain House. 12pp.

Willoughby, M.G. 1995. The effects of grazing on deciduous plant communities in the Boreal Ecoprovince of Alberta. Proceedings of the Fifth Int'l Rangeland Congress, Salt Lake City, Utah. Vol. 1. 610-611.

Willoughby, M.G. 2004. Forage production for the Rangeland Reference Area Program. Unpublished data. Alberta Sustainable Resource Development. Public Lands and Forest Division. Edmonton. Alberta. 
Bibliothèque nationale du Canada 